\title{
New Holocene Capra pyrenaica (Mammalia, Artiodactyla, Bovidae) skulls from the southern Pyrenees
}

\author{
Nouveaux crânes holocènes de Capra pyrenaica (Mammalia, Artiodactyla, \\ Bovidae) des Pyrénées méridionales
}

\author{
Ricardo García-González \\ Instituto Pirenaico de Ecología (IPE-CSIC), Avda. Regimiento Galicia s/n, E-22700 Jaca \\ (Spain), Telf. 0034 974356966, Fax 0034974 363222, rgarciag@ipe.csic.es
}

\begin{abstract}
Three Capra pyrenaica pyrenaica skulls from the Holocene found in different karstic sinkholes in the mid-western Pyrenees are described. Two of the locations were at the highest elevations known for Capra fossils in the Pyrenees, which provides insights into the timing of the Holocene deglaciation. The skulls of the males were particularly large relative to those of other Capra from the Upper Pleistocene found in south-western Europe. An increase in the availability of food, rather than a direct influence of global warming, during the Holocene (Bergmann's Rule) was likely responsible for the large size of the skulls. Comparisons between the horn sections of the Pyrenean skulls and those of neighbouring taxa show a morphological similarity between the former and $C$. $i$. ibex.
\end{abstract}

Keywords: Pyrenean wild goat, Capra evolution, south-western Europe, Caprinae, sexual dimorphism

\section{Résumé}

Trois crânes de Capra pyrenaica pyrenaica de l'Holocène trouvés dans différents avens karstiques dans les Pyrénées centre-occidentales sont décrits. Deux des sites se situent à la plus haute altitude connue pour des restes fossiles de Capra dans les Pyrénées, ce qui est intéressant pour documenter la chronologie de la déglaciation holocène. Les crânes des mâles sont extrêmement grands par rapport aux autres restes de Capra du Pléistocène supérieur trouvés au sud-ouest de l'Europe. Un accroissement de la disponibilité des ressources alimentaires pendant I'Holocène, plutôt qu'une influence directe du réchauffement climatique (règle de Bergmann), fut probablement la cause de la grande taille des crânes. L'étude comparative de la 
section des cornes des crânes pyrénéens (C. p. pyrenaica) et de celles d'autres taxons voisins montre une similitude morphologique entre ces premiers et $C$. $i$. ibex.

Mots clés : bouquetin des Pyrénées, évolution Capra, Europe sud-occidental, Caprinae, dimorphisme sexuel

\section{Introduction}

The Pyrenean wild goat (Capra pyrenaica pyrenaica) is a recently extinct subspecies of the Iberian wild goat (C. pyrenaica) that was characteristic of the Pyrenees, the type species of which was defined by Schinz in 1838 (Cabrera, 1911). The last individual died in Jan 2000, when many of the biological and phylogenetic attributes of this subespecies had yet to be studied (García-González \& Herrero, 1999). Although the taxonomy of extant $C$. pyrenaica at the subspecies level is controversial (Acevedo \& Cassinello, 2009), three other subspecies, all of which are endemic to the Iberian Peninsula, are usually accepted: the extinct $C$. p. Iusitanica from north-western Iberia, C. p. victoriae, which is found in the mountains of central Spain, and C. $p$. hispanica from the south and western sierras of Spain. Taxonomic names follow Shackleton (1997).

Some (Crégut-Bonnoure, 1992; Rivals, 2002) have suggested that C. pyrenaica evolved during the second half of the Upper Pleistocene from an ancestor that is related to $C$. caucasica. That ancestral species would have migrated from the Middle East to Western Europe at the beginning of the last glacial period (120-80 ky). Eventually, it reached southern France and the Pyrenees, where it evolved into $C$. pyrenaica during the Würm III/IV transition (18 ky). That ancestor, named $C$. caucasica praepyrenaica Crégut-Bonnoure, 2002, differed from and did not have contact with the ibex of the Alps (C. i. ibex), which evolved there after a previous migration about 300 ky earlier (Crégut-Bonnoure, 2009). Contrary to that hypothesis, however, the molecular data of extant individuals indicated that $C$. pyrenaica and $C$. ibex share a monophyletic origin (Manceau et al., 1999a).

Numerous remains of $C$. pyrenaica from the Upper Pleistocene and Holocene have been found in southern France and in the northern Pyrenees (Clot \& Duranthon, 1990; Crégut-Bonnoure, 2005; Magniez, 2009; Rivals \& Testu, 2006); however, few remains have been found in the southern Pyrenees (Blasco, 1995). This article describes three Holocene skulls (two adult males, one adult female) found in the southern Pyrenees, which are remarkable because of the high elevation at which two of the findings were made and the exceptional size of the male skulls. I discuss their significance within the context of the ecological conditions in the Pyrenees during the Holocene and their possible influence on sexual dimorphism, based on a theory of caprine evolution (the "dispersal hypothesis" of Geist, 1987 a, b). In addition, some of 
their morphological characteristics are interpreted within the context of current hypotheses on $C$. pyrenaica systematics.

\section{The fossil sites}

The three incomplete skulls of adult Capra (male LAR1, male ORD1, and female ORD2) were found during several speleological explorations by the Estella/Lizarra Speleological Group (GEE/LET), Navarre, Spain, and the Pedraforca Speleological Group (GEP), Barcelona, Spain, in the karstic regions of Larra (Navarre) and Millaris (Ordesa, Huesca, Spain) in the Western and Middle Pyrenees, respectively. Both are notable karst areas, where caves and sinkholes are common. The LAR1, ORD1, and ORD2 skulls were found in sinkholes near the Spanish-French border, and their reference numbers and locations are AN-015 (Larra, Navarra), $0046^{\prime} 57^{\prime \prime} \mathrm{W}-42^{\circ} 56^{\prime}$ 52" N, 1718 m a.s.I.; MS-2 (Millaris, Huesca), 00 2' 47" W - 420 40' 50" N, 2390 m a.s.I.; and CS-59 (Millaris, Huesca), 00 2' 44" W - 420 40' 55" N, 2500 m a.s.l., respectively. The latter two sites are at the highest elevation known for the fossil remains of Capra in the Pyrenees (Clot \& Duranthon, 1990).

The holes in which the skulls were found were structurally similar (Fig. 1). Typically, the entrances to the holes had an inclination of between $30^{\circ}$ and $45^{\circ}$, which led to vertical gaps that varied in depth. Frequently, the hole was interrupted by short horizontal or inclined shelves, where mineral and animal debris accumulated, including the Capra skulls (Fig. 1). Along with other highly decomposed animal remains, which were not removed, the LAR1 skull was found partially buried between the blocks of an alluvial fan at the bottom of the hole. In addition to the ORD1 skull, a scapula and two ribs from another Capra were removed from the site. In addition to the ORD2 skull, 24 of the animal's postcranial bones were collected, some of which were used in $14 \mathrm{C}$ dating. Those remains were found amongst the remains of other Capra sp., Pyrrhocorax sp., and Ursus arctos (Fig. 1). All of the fossil materials are stored in the zoological collections of the Pyrenean Institute of Ecology (CSIC, Spain).

In karstic areas, sinkholes often act as natural traps that lead to the death of some animals because, once they fall into the hole, they cannot escape (Clot \& Evin, 1986), which was the likely origin of the fossils described here, and is relevant because, unlike the remains found in caves that were inhabited by humans and where the remains of hunted animals accumulated (Castaños, 1993; Pailhaugue, 1995), the remains found in the sinkholes can be assumed to have been random samples from the population to which they belonged.

The LAR1 and ORD1 skulls were radiocarbon dated using the AMS Method at the ORAU Laboratory, Oxford University (ref. OxA-6012 and OxA-6013, respectively). The ORD2 individual, which provided more material, was aged using liquid scintillation at the Centre de Datation par le Radiocarbone, University of Lyon (ref. UBAR-448). The 
radiocarbon data were calibrated using the IntCal09 calibration curves of Bronk Ramsey (2009). The estimated ages of the LAR1, ORD1, and ORD2 skulls were 21361774, 3635-3366, and 5221-4842 cal years BC, respectively, which give approximate antiquities of 3900 (LAR1), 5500 (ORD1), and 7000 (ORD2) years BP.

\section{Description of the fossil material}

Skulls were measured using a Vernier caliper ( $0.02 \mathrm{~mm}$ Nonius). Most of the measurements follow Driesch (1976), except the following (Table 1): HN, from the highest (most distal) point of the frontals in the median plane to the distal point of the occipital condyles; HNFM, from the highest point of the frontals in the median plane to the opisthion; HNP, height from the basi-occipital to the top of the parietal; and HVE, from the highest point of the frontals in the median plane to the interesphenoideal suture (measured using a curved calliper). Left and right measurements were averaged, and each average was based on three measurements.

LAR1 was the most complete skull and retains all of the frontal bone including the horn cores (tips broken), the parietal, occipital, and sphenoid bones, two complete orbits with zygomatic arches, nasal bones, and the remains of nasal turbinate in the sinuses (Fig. 2). In the LAR1 skull, the fronto-nasal, middle-frontal, and fronto-parietal sutures are fully merged and not visible. Only a portion of the parieto-occipital suture, the zygomatic bone to the temporal suture (zygomatic arch) and the suture between the pre- and basi-sphenoid are visible. The shape of the horn cores fit the Pyrenean type (Couturier, 1962). The bases of the horns are close and, in its central part, they diverge outward (Fig. 2). Horn cores form a divergence angle of $46^{\circ}$ in the frontal view. Perpendicular sections of the horn core bases are elliptical and the main axis of the ellipsis opens fronto-laterally at a $27^{\circ}$ angle to the median plane in the dorsal view. The nasal bones are abnormally short and have a rectangular shape with parallel sides (except at the tip), which is characteristic of the C. p. pyrenaica subspecies (Cabrera, 1911). The eye orbits are flattened, which is characteristic of $C$. pyrenaica, but unlike Alpine ibexes, which have orbits that are rounded or laterally compressed (Fandos et al., 1993; García-González et al., in prep.).

The ORD1 skull included the braincase, almost the entire right horn core, and the base of the left horn core (Fig. 2). The dimensions of the skull are slightly smaller than those of LAR1 (Table 1), but the horn core is longer and thicker. The right horn core diverges outwards and, distally, they twist slightly inward, indicating a second postero-distal curvature, which is typical of $C$. pyrenaica. Right horn core twists clockwise, indicating the heteronym character of the horns. The divergence angle between horn cores is $45^{\circ}$ in the frontal view. Perpendicular section of the horn core base is elliptical and slightly less compressed than that of LAR1. The main axis opens fronto-laterally at a $16^{\circ}$ angle to the median plane in the dorsal view. All of the 
sutures, including the pre- and basi-sphenoids, are obliterated, which suggests that the ORD1 animal was older than the LAR1 animal.

The skulls of the two males are remarkably large (Fig. 3) and their dimensions greatly exceed those of most of the fossil and extant Capra in south-western Europe (Crégut-Bonnoure, 2009). In the Pyrenees and southern France, only the skulls found in Tournal (Magniez, 2009) and Malarnaud (Griggo, 1991) have dimensions similar to those described here. The C. ibex fossils from Monaco-Grimaldi (Chaix \& Desse, 1983) have slightly higher antero-posterior diameters (DAP) at the horn base, but the transversal diameters (DLM) are similar, and extant $C$. $i$. ibex are significantly smaller in horn thickness. Only a few fossils (C. dalii; Bukhsianidze \& Vekua, 2006) or extant C. caucasica have horns (Couturier, 1962) or skull dimensions (Crégut-Bonnoure, 2009) that are larger than those of the LAR1 and ORD1 skulls (Fig. 3). On the contrary, in the LAR1 and ORD1 skulls, the parietal sagittal length and the size of the foramen magnum are remarkably small compared to other south-western European Capra (Table 1).

The ORD2 skull includes the braincase, the upper portion of the orbits, the lower half of the left horn core and the base of the right (Fig. 2). Interfrontal and fronto-parietal sutures are visible. The suture between the pre- and basi-sphenoids, which does not close (Couturier, 1962) in females, is open. The dimensions were identical to those of extant Pyrenean goats (C. p. pyrenaica), which are significantly greater than those of the other Iberian subspecies (Fig. 4 and García-González et al., in prep.). The ORD2 and extant Pyrenean goats have horns that are slightly thicker than those of Magdalenian C. pyrenaica (13 ky) from La Vache (Pailhaugue, 1995) and Eralla (Altuna et al., 1985), but thinner than those of the Upper Pleistocene female from Castel 2 (Pernaud et al., 2004). In addition, horn width (DLM) is greater than it is in extant C. i. ibex, but the antero-posterior diameter (DAP) is similar, which made the horns of $C$. $i$. ibex more medio-laterally compressed. Fossil C. ibex skulls have larger horns and higher compression indices (DAP/DLM) than do C. p. pyrenaica, but their 95\% C.I. overlap (Fig. 3 and 4). The ORD2 female and females of extant C. $p$. pyrenaica have horns that are significantly thicker than those of extant $C$. caucasica. The compression indices of the horn core bases of female Capra skulls follows a pattern that is similar to that of the males, i.e., an increasing gradient from South Iberia to the Alps (see also García-González, 2011), but the values of females are higher (within the same taxon, the horns of females are more compressed).

\section{Discussion}

Location of the fossil sites 
Unlike in the northern Pyrenees, south-western France, and the Cantabrian Mountains, in the southern Pyrenees, few paleontological deposits of Capra sp. remains have been described. Among the most well known are those from Chaves Cave (Castaños, 1993) and Gabasa Cave (Blasco, 1995) in the Middle Pyrenees, and those from Cova 120, Olopte, Els Ermitons, and Cau del Duc de Torroella in the Eastern Pyrenees (Yravedra, 2004-5). All of those sites are below $1200 \mathrm{~m}$ of altitude. In southern France and the northern Pyrenees, Capra remains from the Upper Pleistocene and Holocene have been found between 350-925 m and between 1190-2240 m, respectively (Clot, 1984). The elevations (2390 and $2500 \mathrm{~m}$ ) at which the fossils from Millaris (ORD1, ORD2) were found were remarkably higher and are the highest known elevations for Capra in the Pyrenees.

In the first half of the Holocene (specifically, at $7 \mathrm{ky}$ ), deglaciation would have already occurred at $2500 \mathrm{~m}$ in Millaris (Ordesa, Central Pyrenees), where traces of the last Pyrenean glaciers remain (Martí Bono \& García Ruiz, 1993). Thus, it can be assumed that, at that elevation, alpine pastures would have already developed above the forest limit, which might have reached 2400 m (González-Sampériz et al. 2005). In addition, a rudimentary pastoral activity might have been present (Miras et al. 2007), which would have increased the amount of alpine grasslands because of the clearing of the alpine forest. During the Holocene, the elevation range of $C$. pyrenaica expanded in the Pyrenees (Clot and Duranthon, 1990). It is very likely that those Holocene goats undertook seasonal vertical migrations to take advantage of the resources in alpine pastures in summer and those in the valley bottoms in winter, just as wild and domestic ungulates do, today (García-González et al. 1990). In alpine environments, seasonal migrations of $C$. ibex can cover more than $1000 \mathrm{~m}$, vertically (Michallet, 1994). In addition, the disappearance of reindeers and horses in the Pyrenees during the Holocene (Altuna, 1992), might have reduced the competition for food and, thereby, increased the amount of food available to goats.

\section{Exceptional size of the male skulls}

The horns of the Pyrenean male skulls (LAR1, ORD1) are considerably larger than those of most of the southern European Capra (Fig. 3). They were larger than the horns of the other Magdalenian (18-10 ky), Holocene, and present-day C. pyrenaica, and were within the upper limit of the sizes of those of pre-Magdalenian Capra ( $C$. caucasica praepyrenaica per Crégut-Bonnoure, 2005)(Fig. 3). In addition, other skull dimensions are larger than those of present-day $C$. pyrenaica subspecies or $C$. ibex (Fandos et al., 1993; García-González et al. in prep.). Usually, body size and horn size are positively correlated (Kitchener, 1985); hence, we can assume that those specimens had large body sizes. The diachronic and fortuitous nature of the male LAR1 and ORD1 findings suggests that the large size of the males is not a bias induced by 
human hunting of the animals, and that they are random samples of their populations. It seems unlikely they would represent outliers in their populations. Therefore, although one or two specimens cannot provide statistical reliability, it is reasonable to postulate that the Pyrenean Holocene males would have had larger horns and body size than they do today.

Typically, two hypothesis are advanced to explain temporal changes in body size within the same or closely related taxa: a metabolic adaptation to changes in air temperature (Bergmann's Rule) (usually, the largest forms of a species occurred during the coldest climates in the past (Kurtén, 1968; Smith et al. 1995)), or a change in the environment lead to changes in the abundance of food resources, which results in changes in body size (Geist 1987a; Purdue \& Reitz, 1993). The reduction in body size in some south-western European ungulates during the Pleistocene-Holocene transition might appear to support the first hypothesis. For example, in northern Spain, the size of Cervus elaphus has decreased since the final Würm (Altuna, 1992), and fossil Alpine ibex are larger than their present-day counterparts (Chaix \& Desse, 1994). If that hypothesis is true, Pyrenean goats from the Upper Pleistocene should have been larger than those that lived during the Holocene, which is contrary to the results shown in the present work.

The apparently large size of male goats in the Pyrenees during the Holocene suggests that they might have been "Ice Age giants" (sensu Geist, 1987a), the hypothetical products of the process in which glaciations led to periods of great environmental alterations and species found new habitats and more food resources. According to Geist's hypothesis, periods of resource abundance are dominated by the dispersive morphs, i.e., individuals that have large body sizes and males that carry large "display organs" (e.g., large horns) that serve to deter competitors, reduce fighting, and give females a visual cue to a male's ability to obtain material resources and the quality of his sperm (Malo et al. 2005). On average, the males that had the largest horns had the greatest reproductive success. In addition, in mountains, migratory populations that can exploit a wide elevational range will have larger body sizes than will individuals in populations that can exploit a narrow range (Geist, 1987b).

With the retreat of the ice during the Holocene, large areas with new food resources became available to the herbivores in the Pyrenees (González-Sampériz et al., 2005). An expanded vertical range allowed a more complete and continuous use of those resources by following new plant growth with elevational displacements throughout the growing season (phenological wave; Morgantini \& Hudson, 1989). The Holocene skulls that were found at the highest elevations indicate that deglaciation had occurred and herbivores likely were taking advantage of alpine grassland resources at that time. Alpine grasslands have high nutritional value (Körner, 1989; Marinas \& García-González, 2006), provide ungulates with fat reserves for winter, and contribute 
to high reproductive potential. Summer feeding is crucial for the survival and reproductive success of mountain ungulates (Albon \& Langvatn, 1992; Pettorelli et al., 2007). The optimization of resource use might have fostered the development of large body size in males during the Holocene in the Pyrenees.

The selection pressures for males to be large are very strong, but not in females, which invest more energy into offspring survival (Geist, 1987b). Rather than investing in the pursuit of reproductive opportunities, females invest in the search for food or parental care, which are not enhanced by an increase in the size of adult females, which might explain why the dimensions of the ORD2 skull are nearly identical to those of present-day female Pyrenean goats (Fig. 4).

\section{Phylogeographical considerations}

Based on skulls found in the Pyrenees that resembled those of Caucasian goats (Pales, 1976-77), and after a thorough study of the dentition of Pyrenean and Alpine Capra, Crégut-Bonnoure (1992) proposed that C. pyrenaica originated from a migration of an ancestor related to $C$. caucasica at the beginning of Würm, which surrounded the Northern Alps, descended along the French Central Massif, and settled in the Pyrenees at the beginning of Magdalenian period (18 ky). C. pyrenaica descended directly from that ancestor related to $C$. caucasica and would not have encountered $C$. ibex, which had become established in the Alps earlier (CrégutBonnoure, 2005). Presumably, the other Iberian subspecies would have differentiated from those Pyrenean goats.

Other paleontological studies suggest that three species (C. caucasica, C. pyrenaica and $C$. ibex) might have coexisted in the Pyrenees during the Upper Pleistocene (Clot and Duranthon, 1990; Pales, 1976-77), or that C. pyrenaica and C. ibex had differentiated, separately, before the Würm, sharing a common ancestor $C$. camburgensis (Chaix \& Desse, 1994; Couturier, 1962).

The hypothesis of Crégut-Bonnoure $(1992,2005)$ appears to be untenable in view of the molecular data and recent paleontological findings. The morphological characters on which the hypothesis relies are highly variable (García-González, 2011; Magniez, 2009). In addition, numerous Capra remains that are older than the final Würm (> 35 ky) have been found in Iberia (García-González, 2011), including two new species of Capra from the Lower Pleistocene found in southern Spain (Arribas \& Garrido, 2008; Made et al., 2008; Moyà-Solà, 1987). Finally, phylogenetic studies based on molecular data have indicated that $C$. ibex and C. pyrenaica have a monophyletic origin and, therefore, are closely related (Kazanskaya et al., 2007; Manceau et al., 1999a; Pidancier et al., 2006). According to Manceau et al. (1999a), the two species form a single clade that excludes species such as $C$. caucasica and, it supports the hypothesis of "a single wave of migration" by the Capra genus into 
Western Europe, which is in contrast to the proposition of Crégut-Bonnoure. The hypothesis of a common ancestor related to $C$. camburgensis seems the most plausible. The recent discovery of a 300 ky Capra from south-eastern Iberia that has been assigned to $C$. cf. camburgensis might provide support for this hypothesis (Sarrión, 2010).

Beyond the hypothesis of Crégut-Bonnoure, other scenarios are possible for the evolution of the south-western European Capra species. Geist (1987b) suggested that C. pyrenaica occupied the Iberian Peninsula during the Riss or earlier, which predates the existence of ibexes in the Alps. The Iberian Peninsula has been a glacial refuge for other old taxa of Pleistocene ungulates; e.g., Rupicapra sp. (Rodríguez et al., 2010), Capreolus capreolus (Randi et al., 2004), and Cervus elaphus (Sommer et al., 2008). Taberlet et al. (1998) suggested that the Pyrenees was a "suture" area where hybridization occurred among taxa in the Iberian refugia and others from central Europe.

It appears that Capra was present in the Iberian Peninsula throughout the Pleistocene (García-González, 2011). The relationship between the ancient Iberian Capra from the Lower and Middle Pleistocene and the common ancestor of C. pyrenaica and $C$. ibex suggested by the molecular data is unknown. Some morphological traits revealed in the present study (Fig. 3 and 4) place Upper Pleistocene, Holocene, and extant $C$. p. pyrenaica close to $C$. $i$. ibex or at an intermediate position between $C$. $i$. ibex and central-southern Iberian Capra, which is compatible with the molecular data, which indicates an equivalent genetic distance of $C$. p. pyrenaica to $C$. $i$. ibex and to central-southern Iberian goats (C. p. victoriae and C. p. hispanica) (Manceau et al. 1999b). An intermediate position of Pyrenean goats might be explained by two nonexclusive hypotheses: Pyrenean goats (C. p. pyrenaica) have maintained some of the genetic traits that are typical of the common ancestor of the two species (C. pyrenaica and $C$. ibex) or a process of hybridization might have occurred more recently (Upper Pleistocene). During the last glaciation, the Iberian goats and ibexes from Middle Europe might have encountered each other in the Pyrenees or surrounding areas. Holocene Pyrenean goats might have incorporated some morphological characters that had been transmitted from Alpine ibex, such as compressed horn core bases (Fig. 3) and large size, which is not incompatible with the Food Abundance Hypothesis of Geist, $(1987 a, b)$.

The origin of $C$. pyrenaica and its differentiation into the present subspecies remains unclear. New paleontological records and more molecular studies of fossils and recent materials probably will be needed to clarify the phylogeny of south-western European Capra and their diversification.

\section{Acknowledgements}


I express my sincere thanks to the Estella/Lizarra and Pedraforca Speleological Groups for collecting the material evaluated in this paper, and A. Senosiain who facilitated the loan of some of the material. I am grateful to A. Fernández-Arias, L. Marquina and E. Villagrasa from Ordesa National Park, J.P. Crampe and J.P. Besson from Parc National des Pyrénées (France), and V. Baldellou, Director of the Provincial Museum of Huesca (Aragón) for the facilities provided for comparative studies. L. Montes (Zaragoza University) provided materials from Gabasa Cave (Huesca). J.L. Sanz assisted with image processing. Comments by M. Esteban, F. Bibi, and F. Fack improved greatly the original manuscript. The Autonomous Government of Aragon partially funded this research.

\section{References}

Acevedo, P., Cassinello, J. 2009. Biology, ecology and status of Iberian ibex Capra pyrenaica: a critical review and research prospectus. Mammal Rev. 39, 17-32. Albon, S.D., Langvatn, R., 1992. Plant phenology and the benefits of migration in a temperate ungulate. Oikos 65, 502-513.

Altuna, J., 1992. El medio ambiente durante el Pleistoceno Superior en la región cantábrica con referencia especial a sus faunas de mamíferos. Munibe 44, 13-29.

Altuna, J., Baldeon, A., Mariezkurrena, K., 1985. Bases de subsistencia de los pobladores de Erralla: Macromamíferos. Munibe 37, 87-117.

Arribas, A., Garrido, G., 2008. Los representantes más antiguos del género Capra (Bovidae, Artiodactyla, Mammalia) en el registro euroasiático (Fonelas P-1, Cuenca de Guadix, España). In: Arribas, A. (Ed.), Vertebrados del Plioceno superior terminal en el suroeste de Europa: Fonelas P-1 y el Proyecto Fonelas. Instituto Geológico y Minero de España, Madrid, pp. 461-473.

Blasco, F., 1995. Hombres, fieras, y presas. Estudio arqueozoologico y tafonomico del yacimiento del Paleolitico Medio de la Cueva de Gabasa 1 (Huesca). Monografias Arqueologicas 38, 1-205.

Bronk Ramsey, C., 2009. Bayesian analysis of radiocarbon dates. Radiocarbon 51 (1), 337-360.

Bukhsianidze, M., Vekua, A., 2006. Capra dalii nov. sp. (Caprinae, Bovidae, Mammalia) at the limit of Plio-Pleistocene from Dmanisi (Georgia). Courier Forschungs-Institut Senckenberg 256, 159-171.

Cabrera, A., 1911. The subspecies of the Spanish ibex. Proceed. Zool. Soc. London 66, 963-977.

Castaños, P.M., 1993. Estudios de los macromamíferos de los niveles paleolíticos de "Chaves". Bolskan 10, 9-30. 
Chaix, L., Desse, J., 1983. Les bouquetins del'Observatoire (Monaco) et des BaousséRoussé (Grimaldi, Italie). Première partie: cranium, atlas, epistropheus. Bulletin du Musée d'Anthropologie Préhistorique de Monaco 26, 41-74.

Chaix, L., Desse, J., 1994. Les Bouquetins fossiles du Sud-Est de la France. Travaux Scientifiques du Parc National de la Vanoise 13, 17-30.

Clot, A., 1984. Grands mammifères piégés dans des cavités des PyrénéesOccidentales. Premières datations au carbone 14. Acta Biologica Montana 4, 389395.

Clot, A., Duranthon, F., 1990. Les mammifères fossiles du Quaternaire dans les Pyrénées. Museum d'Histoire Naturelle de Toulouse, Toulouse, 159 p.

Clot, A., Evin, J., 1986. Gisements naturels Pléistocenes et Holocènes des cavités des Pyrénées Occidentales Françaises: Inventaire et datages 14C. Munibe, 38, 185191.

Couturier, A.J., 1962. Le bouquetin des Alpes (Capra aegagrus ibex ibex L.). Ed. par I' auteur, Grenoble, 1564 p.

Crégut-Bonnoure, E., 1992. Intérêt biostratigraphique de la morphologie dentaire de Capra (Mammalia, Bovidae). Ann. Zool. Fennici 28 (3-4), 273-290.

Crégut-Bonnoure, E., 2005. Nouvelles donnés paléogéographiques et chronologiques sur les Caprinae (Mammalia, Bovidae) du Pléistocène moyen et supérieur d'Europe. Munibe 57 (1), 205-219.

Crégut-Bonnoure, E., 2009. Biochronologie et grands mammifères au Pléistocène moyen et supérieur en Europe occidentale: I'apport des Caprinae de la tribu des Caprini. Quaternaire 20 (4), 481-508.

Driesch, A. von den, 1976. A guide to the measurement of animal bones from archaeological sites. Peabody Museum, Harvard, 1-136 p.

Fandos, P., Aranda, Y., Orueta, J.F., Crégut-Bonnoure, E., 1993. Introduction to skull variability of wild goats (Capra L). Folia Zoologica 42, 111-125.

García-González, R., 2011. Elementos para una filogeografía de la cabra montés ibérica (Capra pyrenaica Schinz, 1838). Pirineos 166, 87-122.

García-González, R., Herrero, J., 1999. El Bucardo de los Pirineos: historia de una extinción. Galemys 11, 17-26.

García-González, R., Hidalgo, R., Montserrat, C., 1990. Patterns of time and space use by livestock in the Pyrenean summer ranges: a case study in the Aragon valley. Mountain Research and Development 10 (3), 241-255.

García-González, R., Vigal, C.R., Fandos, P., in prep. Skull characteristics of the extinct Capra pyrenaica pyrenaica Cabrera, 1914, and its relationships with other neighbouring Capra taxa.

Geist, V., 1987a. On speciation in Ice Age mammals, with special reference to cervids and caprids. Canadian Journal of Zoology 65, 1067-1084. 
Geist, V., 1987b. On the evolution of the Caprinae. In: Soma, H. (Ed.), The Biology and Management of Capricornis and Related Mountain Antelopes. Croom Helm, London, pp. 3-40.

González-Sampériz, P., Valero-Garcés, B.L., Carrión, J.S., Peña-Monné, J.L., GarcíaRuiz, J.M., Martí-Bono, C., 2005. Glacial and Late glacial vegetation in northeastern Spain: New data and a review. Quaternary International 140-141, 4-20.

Griggo, C., 1991. Le bouquetin de Malarnaud (Ariège); implications paléobiogéographiques. Quaternaire 2 (2), 76-82.

Kazanskaya, E., Kuznetsova, M., Danilkin, A., 2007. Phylogenetic reconstructions in the genus Capra (Bovidae, Artiodactyla) based on the mitochondrial DNA analysis. Russian Journal of Genetics 43 (2), 181-189.

Kitchener, A., 1985. The effect of behaviour and body weight on the mechanical design of horns. Journal of Zoology (London) 205, 191-203.

Körner, C., 1989. The nutritional status of plants from high altitudes. Oecologia 81, 379-391.

Kurtén, B., 1968. Pleistocene mammals of Europe. Weidenfeld \& Nicolson, London, 317 p.

Made, J. van der, Carlos Calero, J.A., Mancheño, M.A., 2008. New material of the goat Capra ? alba from the lower Pleistocene of Quibas (Spain): notes on sexual dimorphism, stratigraphic distribution and systematics. Bollettino della Società Paleontologica Italiana 47 (1), 13-23.

Magniez, P., 2009. Nouvelles données sur le genre Capra Linné, 1758 (Mammalia, Bovidae) du Pléistocène supérieur de la grotte Tournal (Bize-Minervois, France): Implications biochronologiques et évolutives. Quaternaire 20 (4), 509 -525.

Malo, A.F., Roldan, E.R.S., Garde, J., Soler, A.J.E., Gomendio, M., 2005. Antlers honestly advertise sperm production and quality. Proceedings of the Royal Society London B 272, 149-157.

Manceau, V., Despres, L., Bouvet, J., Taberlet, P., 1999a. Systematics of the Genus Capra Inferred from Mitochondrial DNA Sequence Data. Molecular Phylogenetics and Evolution 13 (3), 504-510.

Manceau, V., Crampe, J.P., Boursot, P., Taberlet, P., 1999b. Identification of evolutionary significant units in the Spanish wild goat, Capra pyrenaica (Mammalia, Artiodactyla). Animal Conservation 2, 33-39.

Marinas, M., García-González, R., 2006. Preliminary data on nutritional assessment of abundant species in alpine pastures of the Pyrenees. Pirineos. 161, 85-109.

Martí Bono, C., García Ruiz, J.M., 1993. La extensión del glaciarismo cuaternario en el Parque Nacional de Ordesa y Monte Perdido. Geographicalia 30, 271-282.

Michallet, J., 1994. Domaines vitaux et déplacements de bouquetins des Alpes (Capra ibex L.) dans le Massif de Belledonne-Sept Laux: Bilan de deux années de suivi télémétrique. Travaux Scientifiques du Parc National de la Vanoise 239-248. 
Miras, Y., Ejarque, A., Riera, S., Palet, J.M., Orengo, H., Euba, I., 2007. Dynamique holocène de la végétation et occupation des Pyrénées andorranes depuis le Néolithique ancien, d'après l'analyse pollinique de la tourbière de Bosc dels Estanyons (2180 m, Vall del Madriu, Andorre). C.R. Palevol 6 (4), 291-300.

Morgantini, L.E., Hudson, R.J., 1989. Nutritional significance of wapiti (Cervus elaphus) migrations to alpine ranges in Western Alberta, Canada. Arctic and Alpine Research 21 (3), 288-295.

Moyà-Solà, S., 1987. Los bóvidos (Artiodactyla, Mammalia) del yacimiento del Pleistoceno inferior de Venta Micena (Orce, Granada, España). Paleont. i Evol. Mem. Esp. 1, 181-236.

Pailhaugue, N., 1995. La faune de la Salle Monique, Grotte de La Vache (Alliat, Ariège). Bulletin de la Société Préhistorique Ariège-Pyrénées 50, 225-290.

Pales, L., 1976-77. Les ovicapridés préhistoriques franco-ibériques au naturel et figurés. Sautuola 1, 67-105.

Pernaud, J., Quiles, J., Rivals, F., 2004. La faune de la fin du pléistocène dans la haute vallée de l'Aude: I'exemple de la grotte de Castel 2 a Bessede-de-Sault (Aude, France). In: Haesaerts, P., Damblon, F. (Eds.), Acts of the XIVth UISPP Congress, Archaeopress, Oxford, pp. 31-37.

Pettorelli, N., Pelletier, F., Hardenberg, A.v., Festa-Bianchet, M., Côté, S.D., 2007. Early onset of vegetation growth vs. rapid green-up: impacts on juvenile mountain ungulates. Ecology 88 (2), 381-390.

Pidancier, N., Jordan, S., Luikart, G., Taberlet, P., 2006. Evolutionary history of the genus Capra (Mammalia, Artiodactyla): Discordance between mitochondrial DNA and Y-chromosome phylogenies. Molecular Phylogenetics and Evolution 40 (3), 739-749.

Purdue, J.R., Reitz, E.J., 1993. Decrease in body size of white-tailed deer (Odocoileus virginianus) during the Late Holocene in South Carolina and Georgia. In: Martin, R.A., Barnosky, A.D. (Eds.), Morphological change in Quaternary mammals of North America. Cambridge University Press, Cambridge, pp. 281-298.

Randi, E., Alves, P.C., Carranza, J., Milosevic-Zlatanovic, S., Sfougaris, A., Mucci, N., 2004. Phylogeography of roe deer (Capreolus capreolus) populations: the effects of historical genetic subdivisions and recent non-equilibrium dynamics. Molecular Ecology 13 (10), 3071-3083.

Rivals, F., 2002. Les petits bovidés pléistocenes dans le bassin méditerranéen et le Caucase. Etude paléontologique, biostratigraphique, archéozoologique et paléoécologique. Thèse doctorale, Université de Perpignan, Perpignan (France), 418 p.

Rivals, F., Testu, A., 2006. Un nouveau gisement paléontologique à Capra caucasica praepyrenaica: la grotte de I'Arche à Bugarach (Aude, France). C.R. Palevol 5, 711719. 
Rodríguez, T., Pérez, T., Hammer, S.E., Albornoz, J., Domínguez, A., 2010. Integrating phylogeographic patterns of microsatellite and mtDNA divergence to infer the evolutionary history of chamois (genus Rupicapra). BMC Evolutionary Biology 10, 222.

Sarrión, I., 2010. El cáprido del yacimiento de la Cova del Molí Mató, Agres, Alacant. Recerques del Museo d'Alcoi 19, 7-18.

Shacktelon, D.M. (ed.), 1997. Wild Sheep and Goats and their Relatives. Status Survey and Conservation Action Plan for Caprinae, IUCN, Gland \& Cambridge. 390 pp.

Smith, F.A., Betancourt, J.L., Brown, J.H., 1995. Evolution of body size in the woodrat over the past 25,000 years of climate change. Science 270, 2012-2014.

Sommer, R.S., Zachos, F.E., Street, M., Jöris, O., Skog, A., Benecke, N., 2008. Late Quaternary distribution dynamics and phylogeography of the red deer (Cervus elaphus) in Europe. Quaternary Science Reviews 27 (7-8), 714-733.

Taberlet, P., Fumagalli, L., Wust-Saucy, A.-G., Cosson, J.-F., 1998. Comparative phylogeography and postglacial colonization routes in Europe. Molecular Ecology 7 (4), 453-464.

Yravedra Sáinz de los Terreros, J., 2004-2005. Estado de la cuestión sobre la subsistencia del Musteriense de la vertiente mediterránea de la Península Ibérica. Lvcentvm 23-24, 7-17. 
Table 1. Measurements of the Capra pyrenaica skulls in millimetres. In brackets: approximate values. Number in brackets following definition: codes used in Driesch (1976). For acronyms HN, HNFM, HNP and HVE see Description section.

Tableau 1. Mensurations des crânes de Capra pyrenaica en millimètres. Entre parenthèses : valeurs approximatives. Les chiffres entre parenthèses après la définition correspondent aux codes utilisés dans Driesch (1976). Pour les acronymes HN, HNFM, HNP et HVE consulter la section Description.

\begin{tabular}{|c|c|c|c|}
\hline Measurement (mm) & LAR1 & ORD1 & ORD2 \\
\hline Maximum nasal length (15) & 69.6 & & \\
\hline Nasion - Bregma length (10) & 141.5 & & \\
\hline $\begin{array}{l}\text { Parietal length in the sagital } \\
\text { plane }\end{array}$ & 22.4 & $(23)$ & $(37.8)$ \\
\hline Bregma - Akrokranion length (9) & 46.4 & $(59.4)$ & 65.3 \\
\hline Nasion - Akrokranion length (8) & 177.1 & & \\
\hline $\begin{array}{l}\text { Maximum inner height of the } \\
\text { orbit (25) }\end{array}$ & 46.4 & & \\
\hline $\begin{array}{l}\text { Maximum inner length of the } \\
\text { orbit ( } 24)\end{array}$ & 48.6 & & \\
\hline $\begin{array}{l}\text { Maximum inter-orbital width } \\
\text { (34) }\end{array}$ & 169.2 & & $(126.3)$ \\
\hline Minimum inter-orbital width (35) & 128.9 & & \\
\hline Maximum mastoid width (26) & 127.2 & $(109.4)$ & $(81.2)$ \\
\hline Zygomatic width & 165.1 & & \\
\hline Maximum neurocranium breadth & 99.2 & $(96.4)$ & 81.2 \\
\hline Neurocranium length a (HN) & 161.3 & 145.9 & 127.5 \\
\hline Neurocranium length b (HNFM) & 141.0 & 126.0 & 113.1 \\
\hline Braincase height (HNP) & 93.0 & 90.2 & 77.5 \\
\hline Neurocranium height (HVE) & 144.5 & 114.8 & 75 \\
\hline Height of foramen magnum (30) & 20.8 & 19.9 & 21.0 \\
\hline $\begin{array}{l}\text { Maximum breadth of foramen } \\
\text { magnum (29) }\end{array}$ & 21.5 & & 23.2 \\
\hline $\begin{array}{l}\text { Circumference of horn } \\
\text { core base }(40)\end{array}$ & 229 & 236.3 & 105 \\
\hline $\begin{array}{l}\text { Minimum distance between horn } \\
\text { core base }\end{array}$ & 25.5 & 21.1 & 42.6 \\
\hline $\begin{array}{l}\text { Maximum breadth between } \\
\text { lateral borders of horn core base }\end{array}$ & 1439 & & $(1044)$ \\
\hline (32) & & & \\
\hline $\begin{array}{l}\text { Antero-posterior diameter of } \\
\text { horn core base ( } 41)\end{array}$ & 78.5 & 80.3 & 35.2 \\
\hline $\begin{array}{l}\text { Latero-medial diameter of horn } \\
\text { core base }(42)\end{array}$ & 63.6 & 71.1 & 30.5 \\
\hline $\begin{array}{l}\text { Anterior length of horn core } \\
\text { (string) (43) }\end{array}$ & $(350)$ & $(448)$ & \\
\hline
\end{tabular}


Fig. 1. Plans and sections of sinkholes where skulls of Capra pyrenaica were found (asterisks). Adapted from drawings of GEE/LET and GEP.

Fig. 1. Plans et coupes des avens où les crânes de Capra pyrenaica (astérisques) ont été trouvés. Adapté à partir des dessins de GEE/LET et GEP.

Fig. 2. LAR1 (above), ORD1 (middle) and ORD2 (bottom) Capra pyrenaica skulls in frontal and lateral view. Scale bar $=5 \mathrm{~cm}$.

Fig. 2. Crânes des Capra pyrenaica LAR1 (au-dessus), ORD1 (centre) et ORD2 (en bas) en vue frontale et latérale. Échelle $=5 \mathrm{~cm}$.

Fig. 3. Bivariate plot of longitudinal (DAP) and transverse diameter (DLM) of basal horn core section of some European extant and fossil Capra males. Mean values and 95\% confidence limits (thin lines). Open triangles: extant $C$. ibex from Chaix et Desse (1983) below and Couturier (1962) above. Filled triangle: Riss-Würm C. ibex from Chaix \& Desse (1983). Open squares: extant C. pyrenaica (own data), from bottom to top: C. p. hispanica (Cazorla Sierra), C. p. victoriae (Gredos Sierra), C. p. pyrenaica (Pyrenees). Filled squares: Magdalenian C. pyrenaica from Pailhaugue (1995) below, and Pyrenean Holocene C. pyrenaica from Clot (1988) and own data (above). Open squares with dot: LAR1 below-left, ORD1 above-right (this study). Open diamonds: extant C. caucasica-cylindricornis from Couturier (1962) above, and Rivals (2002) below. Filled diamonds: above, Middle Würm C. pyrenaica from Spanish PrePyrenees (Gabasa cave) own data; below, mean of South-French Lower-Middle Würm skulls of C. caucasica praepyrenaica (sensu Crégut-Bonnoure, 2005), data from Griggo (1991), Rivals (2002) and Magniez (2009). Crosses: old Capra (>1 My), above: C. dalii (Georgia), below: C. baetica (South Spain) from Arribas \& Garrido (2008), middleleft: C. alba (South Spain) from Moyà-Solà (1987) and Made et al. (2008). Open and filled circles: extant and fossil Hemitragus jemlahicus from Rivals (2002).

Fig. 3. Graphique bivarié du diamètre longitudinal (DAP) et transversal (DLM) de la section basale des chevilles osseuses de Capra mâles européens actuels et fossiles. Valeurs moyennes et limites de confiance à 95\% (lignes minces). Triangles blancs : C. ibex actuels; en bas d'après Chaix \& Desse (1983), au-dessus d'après Couturier (1962). Triangle noir : C. ibex du Riss-Würm d'après Chaix \& Desse (1983). Carrés blancs : C. pyrenaica actuels (données personelles), de bas en haut: C. p. hispanica 
(Cazorla Sierra), C. p. victoriae (Sierra de Gredos), C. p. pyrenaica (Pyrénées). Carrés noirs : en bas $C$. pyrenaica du Magdalénien d'après Pailhaugue (1995), en haut $C$. pyrenaica de I'Holocène (d'après Clot 1988 et données personnelles). Carrés blancs avec point : en bas à gauche LAR1, en haut à droit ORD1 (cette étude). Losanges blancs : C. caucasica-cylindricornis actuels d'après Couturier (1962) en haut et Rivals (2002) en bas. Losanges pleins : au-dessus, C. pyrenaica du Würm moyen des PréPyrénées espagnoles (grotte de Gabasa, données personnelles); en bas, moyenne des crânes du sud de la France du Würm moyen-récent ( $C$. caucasica praepyrenaica selon Crégut-Bonnoure, 2005), données de Griggo (1991), Rivals (2002) et Magniez (2009). Croix : anciennes Capra (>1 Ma), en haut C. dalii (Géorgie), en bas $C$. baetica (sud de l'Espagne) d'après Arribas \& Garrido (2008), au milieu à gauche C. alba (sud de l'Espagne) d'après Moya-Solà (1987) et Made et al. (2008). Cercles blancs et noirs : Hemitragus jemlahicus actuels et fossiles d'après Rivals (2002).

Fig. 4. Bivariate plot of longitudinal (DAP) and transverse diameter (DLM) of basal horn section of some European living and fossil Capra females. Mean values and $95 \%$ confidence limits (thin lines). Open triangles: extant Alpine $C$. ibex from Chaix et Desse (1983) below, and Couturier (1962) above. Filled triangles: Riss-Würm C. ibex from Chaix et Desse (1983) and C. camburgensis from Made et al. (2008). Open squares: extant C. pyrenaica (own data), from top to bottom: C. p. pyrenaica (Pyrenees), C. p. victoriae (Gredos Sierra), C. p. hispanica (Cazorla Sierra). Filled squares: Magdalenian C. pyrenaica from Eralla (Altuna et al., 1985) below, from La Vache (Pailhaugue, 1995) middle, and Castel 2 (Pernaud et al., 2004) above. Open square with dot: Holocene $C$. pyrenaica (ORD2 this study). Open diamond: extant C. caucasica-cylindricornis from Couturier (1962). Cross: C. alba from Quibás (South Spain) (Made et al. 2008).

Fig. 4. Graphique bivarié du diamètre longitudinal (DAP) et transversal (DLM) de la section basale des chevilles osseuses de Capra femelles européennes actuelles et fossiles. Valeurs moyennes et limites de confiance à 95\% (lignes minces). Triangles blancs : C. ibex actuels; en bas d'après Chaix \& Desse (1983), au-dessus d'après Couturier (1962). Triangles noirs : C. ibex du Riss-Würm (Chaix \& Desse, 1983) et C. camburgensis (Made et al. 2008). Carrés blancs : C. pyrenaica actuels (données personnelles), de haut en bas : C. p. pyrenaica (Pyrénées), C. p. victoriae (Sierra de Gredos), C. p. hispanica (Cazorla Sierra). Carrés noirs : C. pyrenaica du Magdalénien d'Eralla (Altuna et al., 1985) en bas, de La Vache (Pailhaugue, 1995) au milieu, et de Castel 2 (Pernaud et al., 2004) en haut. Carrés blancs avec point : C. pyrenaica de I'Holocène (ORD2 cette étude). Losange blanc : $C$. caucasica-cylindricornis actuels d'après Couturier (1962). Croix : C. alba de Quibás (sud de l'Espagne) d'après Made et al. (2008). 

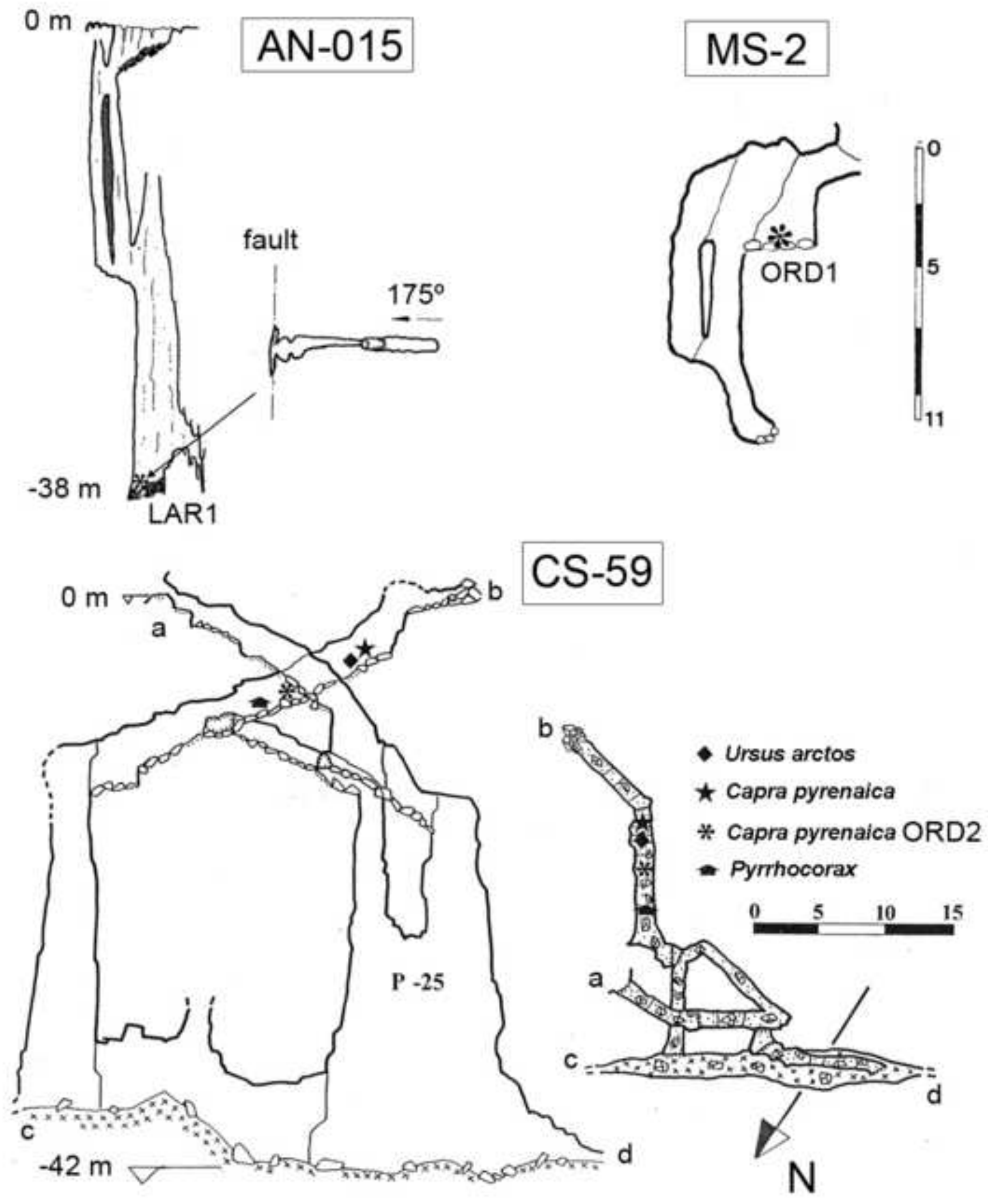

MS-2 
Figure
Click here to download high resolution image
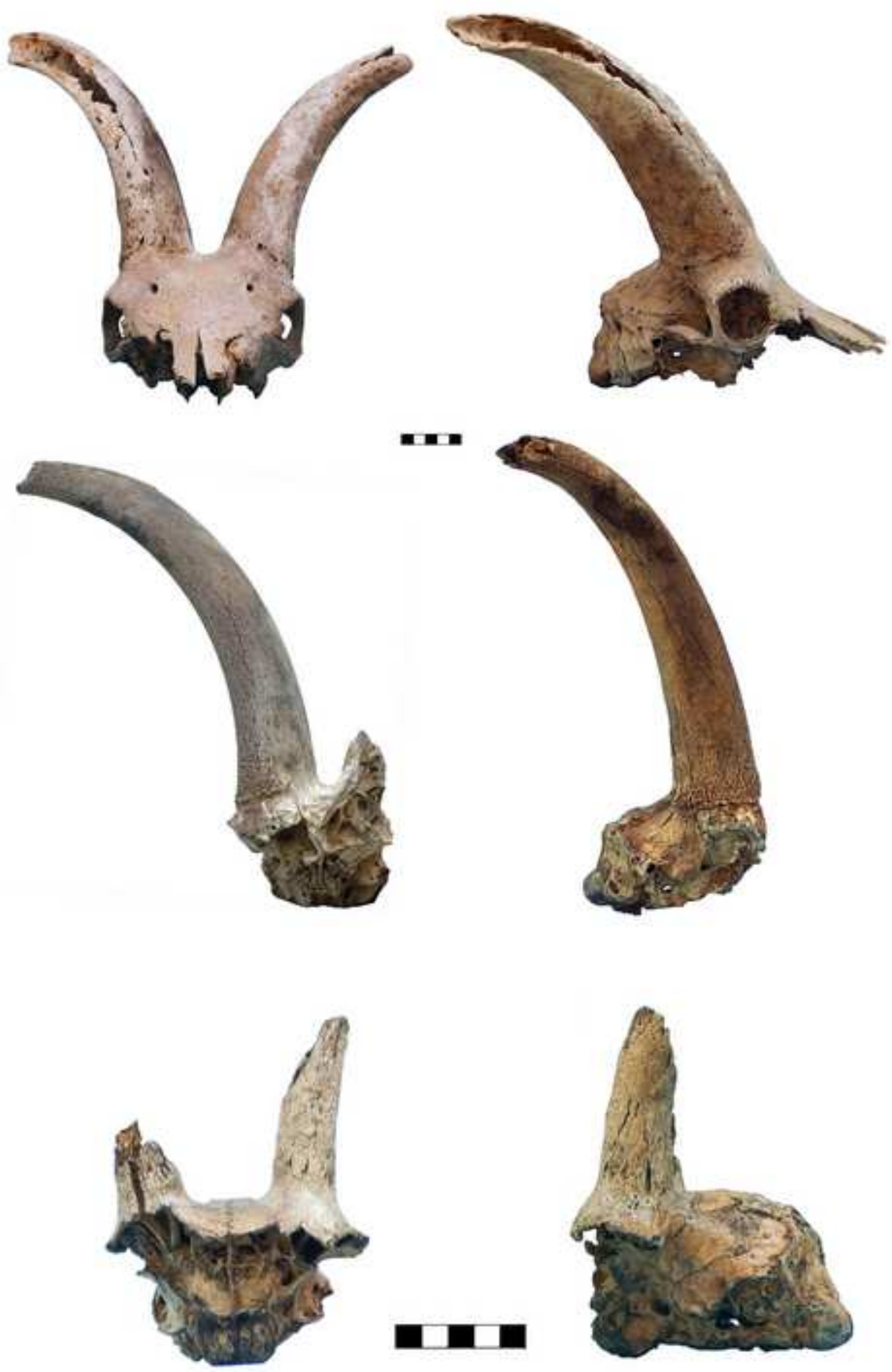
Click here to download high resolution image

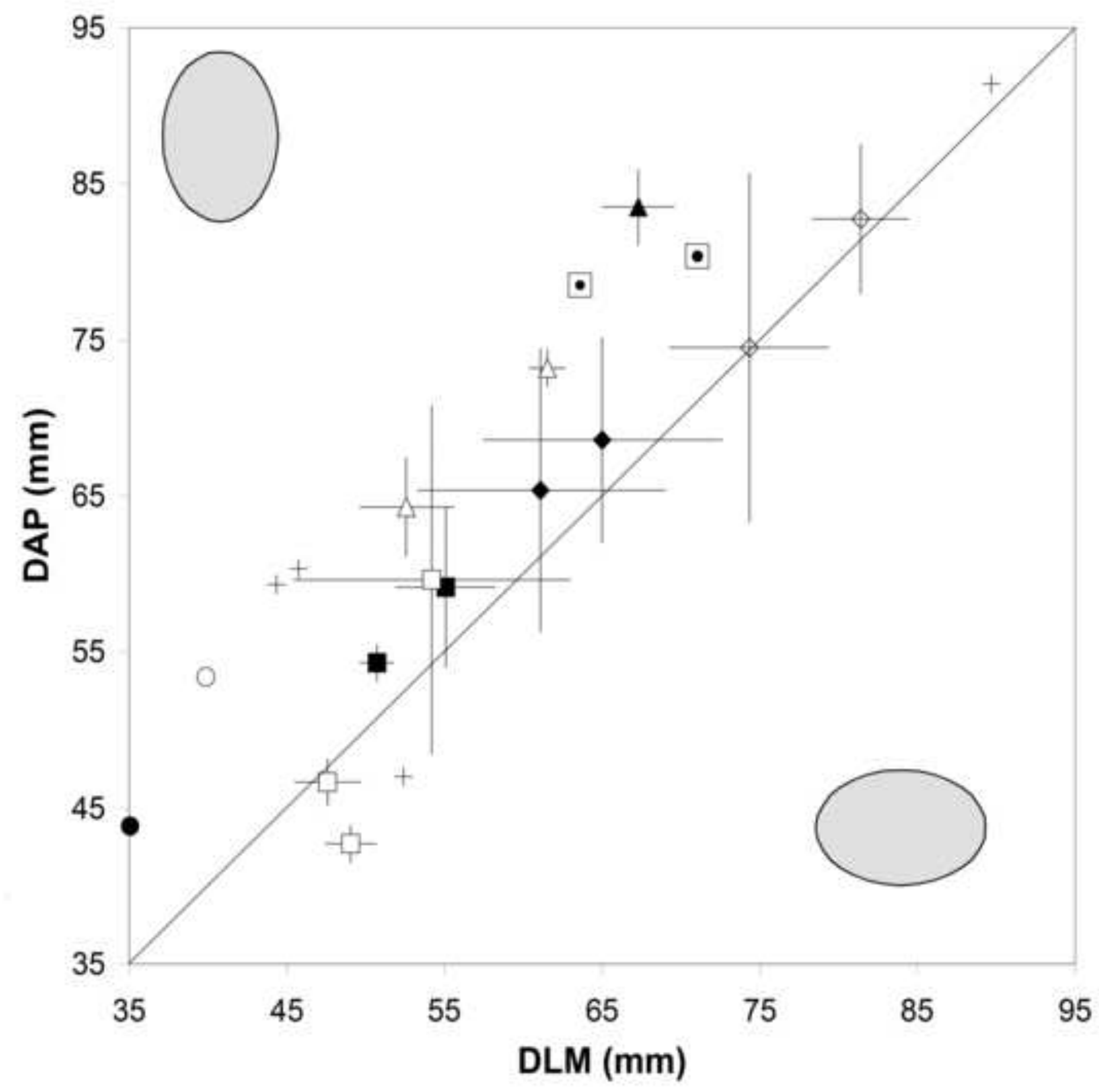


Click here to download high resolution image

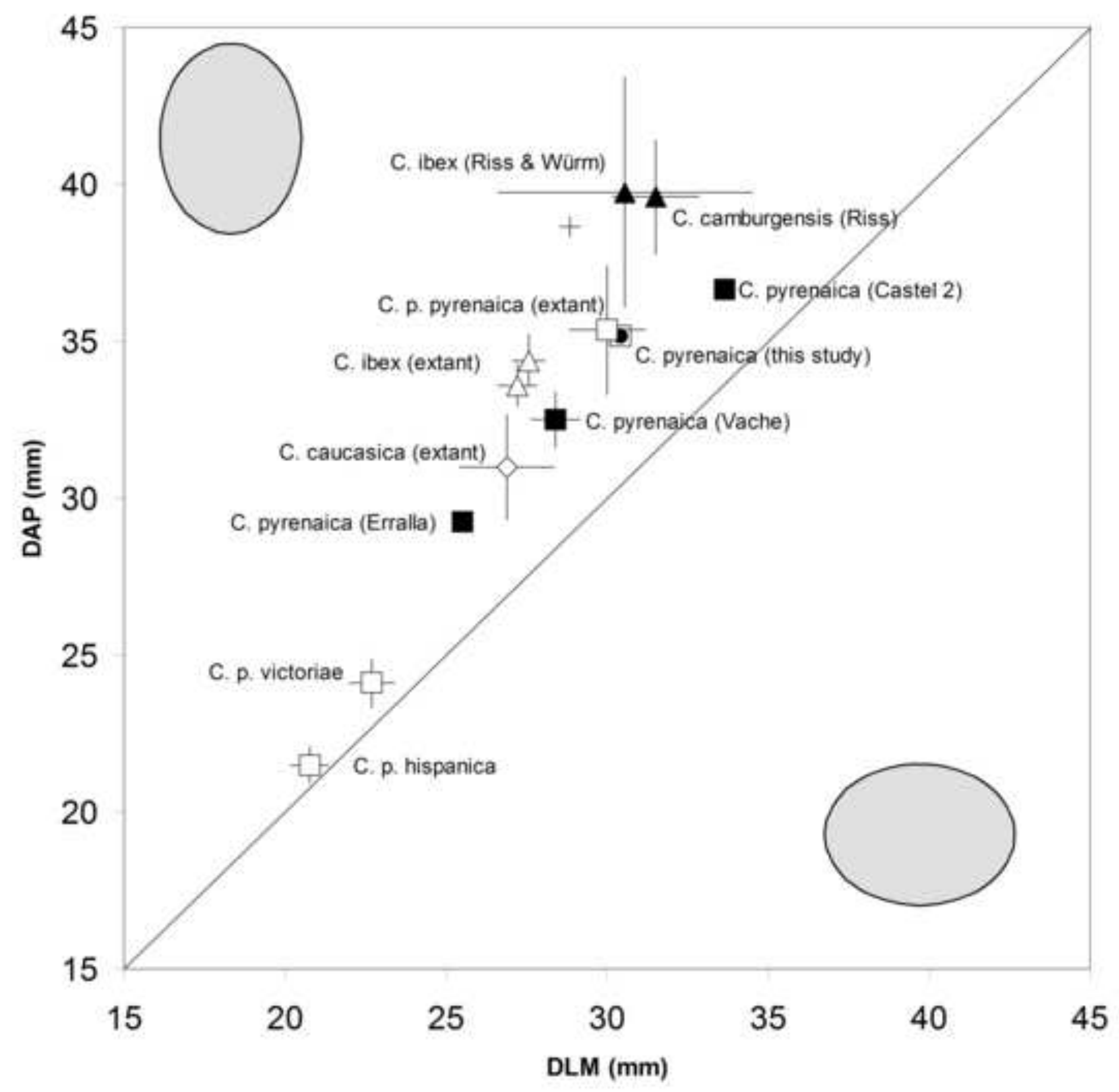

